\title{
Niedokończony spór z abp. Józefem Życińskim o rozumienie ludowości
}

PROF. DR HAB. JERZY BARTMIŃSKI

Uniwersytet Marii Curie-Skłodowskiej w Lublinie

1. Odważam się wystąpić w gronie bliskich przyjaciół i współpracowników nieodżałowanego abp. Józefa Życińskiego, choć sam należałem do dalszego kręgu jego znajomych. Ale od kiedy go poznałem, miałem nieodparte wrażenie pewnej duchowej bliskości połączone z respektem i podziwem dla jego onieśmielającej mnie inteligencji. W pewnym momencie zdałem sobie sprawę, że - chociaż obaj pochodzimy z rodzin kolejarskich - różnimy się radykalnie, jeśli chodzi o stosunek do tzw. ludowości. Ludowości jako idei, w sensie kulturowym, nie ideologicznym. Chciałem podjąć z nim dyskusję na ten temat zwłaszcza w kontekście „ludowej pobożności”, „ludowego katolicyzmu", zawartych w nim wartości, ale zdążyliśmy zaledwie zasygnalizować sobie pewne - dość istotne - rozbieżności polegające na jego krytycznym, a moim aprobatywnym podejściu do folkloru i do kultury ludowej w ogólności. Dało tu znać o sobie ambiwalentne wartościowanie pojęcia „ludu” 
i „ludowości” w kręgach kościelnych i inteligenckich. Nie brak opinii, że są to pojęcia socjologicznie przestarzałe, politycznie skompromitowane, a kulturowo wstydliwe. Nie podzielam tych opinii. Choć pochodzę z rodziny miejskiej, jako polonista, folklorysta, etnolingwista, ostatnio poniekąd też antropolog, odkryłem - i wciąż jeszcze odkrywam w tradycyjnej kulturze ludowej wartości wykraczające poza obiegowy stereotyp folkloru i ludowości. Uważam, że wartości te nie zostały należycie rozpoznane, i o tym chciałem rozmawiać z abp. Życińskim. Odniosłem - by tak rzec - niepełny sukces. Zapewne byłem za mało przekonujący, może nawet śmieszny z zamiarem „nawracania księdza biskupa na folklor" (jak ktoś się uszczypliwie wyraził), dyskusji nie zdążyliśmy dokończyć. Dlatego wracam do tematu. Opowiem krótko o kilku etapach naszych rozmów, które choć niedokończone - były dla mnie bardzo pouczające.

2. Pierwsze moje spotkanie z ks. Życińskim miało miejsce w Waszyngtonie w USA w roku 1989. Uczestniczyłem we Mszy św., jaką ks. Józef Życiński - jeszcze jako profesor z Krakowa - odprawił dla tamtejszej Polonii, a na spotkaniu po Mszy wygłosił wykład - po angielsku - o zasługach polskiego Kościoła dla kultury narodowej, o spotkaniach z poetami, artystami, aktorami itd., krytycznie nastawionymi do komunistycznej władzy. Zapytałem go, co sądzi o osławionej „ludowości” polskiego katolicyzmu. Ksiądz profesor - wtedy jeszcze nie biskup - nie podjął tematu, powiedział, że o tym pogadamy w kraju. Od tego momentu zaczęła się moja pogoń za nim, z nadzieją na dokończenie 
rozmowy. Chciałem rozmawiać z jednej strony o chrystianizacji polskiej kultury ludowej, ale z drugiej też o folkloryzacji polskiego katolicyzmu współczesnego.

3. W kraju pierwsza okazja nadarzyła się na konferencji „Kolędy w krajach słowiańskich - geneza, rozwój, stan obecny", którą w roku 1995 zorganizował Instytut Filologii Polskiej krakowskiej WSP z udziałem Instytutu Teologicznego PAT w Tarnowie. Opiekunem naukowym konferencji był - już wówczas biskup tarnowski - ks. Józef Życiński, który też wygłosił znakomite wprowadzenie do obrad pt. „Paradoksy Bożych Narodzin” poświęcone „promieniowaniu boskości” i „sile bezsilnych”. Tę siłę dostrzegał „w życiu takich osób jak Biedaczyna z Asyżu i Proboszcz z Ars, utrudzona matka Teresa z Kalkuty czy intelektualizująca Simone Weil”. Wystawiłem się i ja z referatem o „ludowych kolędach apokryficznych”, chcąc pokazać estetyczne i poetyckie wartości zwłaszcza mało znanych kolęd maryjnych, o takich incipitach: „Najświętsza Panienka po świecie chodziła”, „Stała nam się nowina miła”, „Zajaśniała śliczna gwiazda na niebie”, „Na zielonej łące, pszenicznej dolinie”, „Stoi tu lipeńka, lipeńka zielona" itp. Wymieniam tu tylko niektóre z utworów opublikowanych w krakowskiej oficynie Universitas w antologii pod tytułem Polskie kolędy ludowe $e^{1}$. Żeby Państwu przybli-

1 Polskie kolędy ludowe. Antologia, oprac. J. Bartmiński, Kraków 2001. Było ich równo 150, więc Jan Turnau w swojej recenzji w "Gazecie Wyborczej” nazwał zbiór „ludowym Psałterzem”. 
żyć temat, przytoczę jedną z najciekawszych kolęd, należącą do cyklu „rozmów z Maryją”:

Zajaśniała śliczna gwiazda na niebie, Porodziła Panna Syna w potrzebie.

A gdzie żeś Go porodziła, Maryja?

Tu w stajence, między bydłem, lilija.

A gdzie żeś Go Ty kąpała, Maryja?

Jest w źródełku zimna woda, Wykąpałam Pana Biga, lilija.

A w co żeś Go owijała, Maryja?

Są w kościele firaneczki, Będą z tego pieluszeczki, lilija.

A gdzie żeś Go kołysała, Maryja?

Między dwoma ołtarzami, jest kolebka ze świecami, lilija.

A kto będzie Go kołysał, Maryja?

Święty Szczepan i święty Jan, lilija.

A kto Mu będzie śpiewał, Maryja?

Przyjdą z nieba aniołowie zaśpiewają Jezusowi: „Gloryja”!

Kolędy tego typu nie są trywialnymi pastorałkami o przygodach pasterzy idących do Betlejem, różnią się też od kolęd kościelnych. Ewangeliczny wątek narodzin Jezusa rozwijany jest w konwencji sztuki naiwnej, są realistyczne (matka po urodzeniu dziecka kąpie je, kołysze, śpiewa mu, w niektórych tekstach także karmi), 
operują symbolicznymi obrazami zielonej łąki, białego kamienia, wody i drzewa lipowego, a zarazem eksponują dramat ubogiego macierzyństwa, cud objawiania się sacrum (m.in. krzesania ognia z lodu czy cudownego wzrostu pszenicy, klękania psów przed Maryją, którą jako „brzemienną pannę z dzieckiem" gospodarz chce wyszczuć ze wsi itp.). Kolędy apokryficzne nie są w ogóle notowane w licznych kantyczkach wydawanych przez duchownych. Są rdzennym tworem ludowym, należą do autentycznego folkloru religijnego. Są przykładem zakorzenienia przekazu Ewangelii w kulturze ludowej i kodowania Dobrej Nowiny z wykorzystaniem narzędzi językowych tej kultury. Dodam na marginesie, że ludowy obraz Matki Jezusa jest w tych ludowych kolędach bliższy Ewangelii niż obecny w oficjalnym kościelnym dyskursie obraz Maryi - królowej Polski, hetmanki, obronczyni narodu, a autentyczna maryjność ludowa różni się od maryjności kościelno-narodowej, masowej, „częstochowskiej”.

Niestety, prezentacja ludowych kolęd nie stała się okazją do rozmowy o wartościach tkwiących w religijnym folklorze, bo ksiądz biskup zaraz po wygłoszeniu swojego przemówienia wyjechał, mojego referatu nie zdążył wysłuchać. Jakiś czas po konferencji zaprosił mnie co prawda z odczytem do Tarnowa, niestety, zanim zdążyliśmy uzgodnić

2 O czym więcej zob. J. Bartmiński, Matka Boska w polskiej tradycji ludowej, „Przegląd Powszechny” nr 5 (2004), s. 271-281; nr 6, s. 279-29o; oraz E. Rosa, Typy Madonny w polskiej literaturze ludowej, „Literatura Ludowa" nr 3 (1986), s. 19-55. 
termin mojego wystąpienia, ks. Józef Życiński został ordynariuszem diecezji lubelskiej. Był to rok 1997.

4. W Lublinie nastąpił drugi etap naszych kontaktów, szczególnie dla mnie interesujących, ale dotyczących już innych spraw, ogólniejszych, bardzo ważnych ${ }^{3}$. Arcybiskup był niezwykle aktywny na wielu polach, organizował wiele spotkań i konferencji. We wrześniu roku 2000 odbył się Kongres Kultury Chrześcijańskiej, który w intencji metropolity lubelskiego miał „skupić uwagę na tych chrześcijańskich inspiracjach kultury, które [...] winny stać się dziedziną bliskiej współpracy zarówno ludzi Kościoła, jak i twórców kultury"4. Jednak temat ludowego chrześcijaństwa na Kongresie nie pojawił się w ogóle, choć mówiono (w referatach Stefana Sawickiego, Adama Bonieckiego, Grzegorza Górnego, Władysława Panasa) o potrzebie łączenia uniwersalizmu katolickiego $\mathrm{z}$ tradycją narodową ${ }^{5}$.

3 Chodziło m.in. o działalność gremium partnerskiego KAAD (Katholischer Akademischer Ausländer Dienst), które typowało kandydatów na studia do Niemiec, a które na mocy ustaleń prawnych powoływać miał prawo metropolita. Jako przewodniczący lubelskiego gremium, powołany przez abp. Bolesława Pylaka, złożyłem nowemu biskupowi sprawozdanie $z$ dotychczasowej działalności gremium, a ten okazał mi zaufanie i przedłużył mandat przewodniczącego.

4 Cyt. za: Sacrum i kultura. Chrześcijańskie korzenie przyszłości, red. R. Rubinkiewicz, S. Zięba, Lublin 2000, s. 381-382. Zostałem zaproszony do panelu pod hasłem „Etos akademicki a odpowiedzialność za kulturę" i wygłosiłem referat pt. Czy kulawy może pomóc chromemu?, zob. tamże, s. 323-331.

$5 \mathrm{Na}$ refleksję nad ludowością naszej kultury zabrakło miejsca na odbywanym w tym samym roku elitarnym Kongresie Kultury Polskiej, zob. Kongres Kultury Polskiej. Warszawa 7-10 grudnia 200o, 
Temat nie pojawił się także w roku 2008 w czasie III Kongresu Kultury Chrześcijańskiej pn. „Godność czy sukces? Kulturowe dylematy współczesności” (uczestniczyłem w panelu „Co nam zostało z ideałów Sierpnia?”).

5. W roku 2010 abp Życiński przyjął moje zaproszenie do udziału w dyskusji panelowej pt. „Jakie wartości tworzą «duszę» Europy u progu XXI wieku”, pojawił się na Uniwersytecie Marii Curie-Skłodowskiej. W referacie pt. „Dusza Europy” a godność człowieka zarysował „horyzont aksjologiczny przyszłej Europy” i stwierdził, że „nie będzie możliwe do przyjęcia pojęcie «duszy Europy», jeśli odrzuci się koncepcję nienaruszalnej godności człowieka" ${ }^{\circ}$. W świecie ludzkich wartości na wysokim miejscu po raz kolejny umieścił solidarność, którą łączył - jako filozof i etyk - z bezinteresownością i poświęceniem. Powiedziałem mu wtedy,

red. S. Bednarek i in., Wrocław 2002. Przed warszawskim Kongresem, w dniach 11-14 listopada 2000 roku odbył się Lubelski Kongres Kultury Polskiej, na którym pojawił się blok referatów pt. „Kultura ludowa i wsi współczesnej", był jednak pomyślany jako prezentacja działań instytucjonalnych, bez podejmowania pytań o wartości kultury ludowej i jej związki $z$ religią. Językoznawcy $w$ ramach tegoż kongresu zorganizowali ( $w$ dniach 26-28 października 200o) własną konferencję pt. „Język w kręgu wartości”. Arcybiskup Życiński przyjął zaproszenie do udziału w tej konferencji i wygłosił słowo wstępne, w którym podkreślał „więź merytoryczną" między naszą konferencją (i Kongresem) a Kongresem Kultury Chrześcijańskiej, mówił o konieczności przezwyciężania lęku, z którego początek biorą agresja i konflikty. Tematu ludowego chrześcijaństwa jednak nie poruszył. Materiały z tej konferencji - ze słowem Arcybiskupa - wyszły drukiem jako: Język w kręgu wartości, red. J. Bartmiński, Lublin 2004.

6 Tekst wystąpienia ks. abp. został opublikowany w „Etnolingwistyce" nr 23 (2011), s. 19-23. 
że solidarność jest z genezy ideą ludową, tyle tylko, że w tradycji ludowej nie zakłada bezinteresowności i gotowości do poświęcenia. Na wzmiankę o ludowości Arcybiskup zbył mnie słowami: „Ludowość? Jak się chłopaki na zabawie w remizie popiją, to w ruch idą sztachety i tyle!". Wtedy zrozumiałem, że Arcybiskup musiał mieć jakieś negatywne doświadczenia w zetknięciu się z wiejskimi zwyczajami i że myśli o ludowości w kategoriach ściśle bytowych, pragmatycznych, a nie kulturowych.

6. Nie dałem za wygraną. Ponieważ Arcybiskup wielokrotnie nawiązywał do pojęcia solidarności międzyludzkiej jako cnoty chrześcijańskiej i był jej gorliwym, radykalnym głosicielem ${ }^{7}$, postanowiłem go przekonać, że idea solidarności tkwi korzeniami w kulturze chłopskiej i jest ideą najgłębiej ludową. Przygotowałem sążnisty artykuł o solidarności. Napisałem w nim, że choć samo słowo „solidarność” w języku ludowym nie występuje, to pojęcie solidarności tkwi w centrum ludowego systemu wartości. Powołałem się na współczesnych socjologów. Przywołałem opinię profesora Józefa Styka, że „poczucie solidarności społecznej stanowiło podstawę życia członków grupy" i na gruntownie uzasadnioną opinię dwóch innych socjologów - Williama Thomasa i Floriana Znanieckiego, którzy w pięciotomowym dziele Chłop polski $w$ Europie i w Ameryce ${ }^{8}$ dowodzili, że so-

7 Do solidarności abp Życiński nawiązywał wielokrotnie, zob. J. Życiński, Samotność wśród liberatów, Lublin 2004, s. 107.

8 Dzieło to, wydane po angielsku w roku 1918, ukazało się po polsku w roku 1976. 
lidarność z bliskimi ludźmi, solidarność ze wszystkim, co żyje, służąca ochronie życia, „solidarność z życiem” - stanowiła centralną zasadę aksjologiczną tradycyjnej kultury chłopskiej, była podstawową ideą porządkującą życie wspólnoty ${ }^{9}$, co rzecz jasna nie wyklucza udziału w jej rozwijaniu chrześcijaństwa i nauczania Kościoła (z jego nauką opartą o Pawłowe „jedni drugich ciężary noście”). Ale istotą solidarności jest myślenie i działanie wspólnotowe, wzajemna pomoc, także równość i jedność, wymagająca zwykle ograniczenia indywidualnej wolności wyboru. Arcybiskup Życiński był głosicielem zarówno idei wolnościowych, jak solidarnościowych, a kładąc duży nacisk na wspólnotowość, w naturalny sposób wpisywał się w aksjologię ludową. Sprzeczności między wolnością a solidarnością Arcybiskup - o ile się orientuję - nigdzie nie komentował.

7. Trzeci i najważniejszy ważny etap w moim niedokończonym dialogu z Arcybiskupem na temat ludowości nastąpił w roku 2010 - roku beatyfikacji ks. Jerzego Popiełuszki. Pewnego dnia sam Arcybiskup zadzwonił do mnie - było to w marcu albo kwietniu - i zaproponował, żebym przygotował prelekcję o ks. Jerzym i wygłosił ją w którymś z lubelskich kościołów w ramach przygotowań do beatyfikacji ks. Jerzego. Zgodziłem się bez wahania ${ }^{10}$. A kiedy pracowałem nad tematem, doznałem olśnienia,

9 W. Thomas, F. Znaniecki, Chłop polski w Europie i $w$ Ameryce, t. 2, Warszawa 1976, s. 174 i nast.

10 Wykład odbył się w kościele na Czubach 23 maja 2010 roku o godz. 19.00, po mszy wieczornej. 
zrozumiałem, że ks. Jerzy Popiełuszko w kwestii wartości ludowości jest postacią kluczową, bo dostarcza ważnego argumentu w dyskusji na temat wartości ludowego chrześcijaństwa. I przesyłając tekst wykładu abp. Życińskiemu, zatytułowałem go nieco prowokacyjnie: „Jerzy Popiełuszko jako bohater ludowy". Rozwinąłem argumentację, którą w skrócie podam.

Przyjąłem, że Jerzy Popiełuszko jest „bohaterem ludowym" w pełnym tego słowa znaczeniu. Jest bohaterem - bo zachował się odważnie w niebezpiecznej sytuacji, narażając swoje życie, dokonał niezwykłych czynów, wzbudzających podziw. Wyrósł wysoko ponad przeciętność. A bohaterem ludowym po pierwsze dlatego, że pochodził z ludu, po drugie, pracował „dla ludu”, to znaczy dla wszystkich; po trzecie, był akceptowany przez lud. Był synem rodziny chłopskiej, był wyrazicielem uczuć $i$ aspiracji szerokich kręgów społecznych w konfrontacji z opresyjną władzą, ówczesną elitą polityczną, trafił ze swoim przesłaniem do wszystkich ludzi w Polsce i nie tylko.

Co łączyło abp. Józefa Życińskiego z ks. Jerzym Popiełuszką? Mimo że warunki polityczne, w jakich obaj działali, były radykalnie różne, jeden element był im obu wspólny: rozumienia wspólnoty ludzkiej jako wspólnoty przede wszystkim duchowej, opartej na wspólnie wyznawanej wierze i na wartościach ewangelicznych, wspólnoty jako Ludu Bożego. Ożywiała ich obu chęć służenia innym z całkowitym oddaniem i poświęceniem. Różnili się natomiast znacznie, jeśli chodzi o rozumieniem narodu. 
Ksiądz Popiełuszko nadawał narodowi szczególną rangę, przejął teologię narodu kardynała Wyszyńskiego, posługiwał się wypracowanym w XIX wieku, w okresie narodowej niewoli językiem religijno-patriotycznym. Zgodnie z polską tradycją romantyczną ks. Popiełuszko łączył lud i naród w jedną całość, dodawał niekiedy jeszcze społeczeństwo ${ }^{11}$, mówił o wspólnym wszystkim prawie do wolności i godności ${ }^{12}$. Ale równocześnie pojęcie wspólnoty - narodowej, zawodowej czy obywatelskiej - odnosił stale do religijnej idei Ludu Bożego jako wspólnoty wartości. Lud, naród, społeczeństwo i jego wyróżnione grupy zawodowe traktował jako wspólnoty cząstkowe, a pojęcie Ludu Bożego było dla niego kategorią nadrzędną, wszechogarniającą.

I na tym poziomie ks. Jerzy i abp Życiński byli jednomyślni. Natomiast obaj duchowni rozeszli się, jeśli chodzi o stosunek do kategorii narodu. W przypadku ks. Popiełuszki utożsamienie pojęcia narodu i Ludu Bożego ${ }^{13}$ prowadziło

${ }_{11}$ Na przykład w kazaniu z 30 stycznia 1983 roku - w rocznicę powstania styczniowego.

${ }^{12}$ „Rozpoczęła się w społeczeństwie rewolucja moralna”; „patriotyzm narodu wywodził się z autentycznej troski o przywrócenie Ojczyźnie pełnej wolności”; „lud [...] poderwał się do powstania zbrojnego” itp. 28 sierpnia 1983 roku mówił: „naród miał prawo oczekiwać, że zakończenie stanu wojennego i amnestia [...] przywrócą społeczeństwu podmiotowość”. Z kolei 28 lutego 1982 roku powiedział: „Powołanie do wolności jest prawem każdego człowieka i narodu” (cyt. za: ks. J. Popiełuszko, Kazania 1982-1984, Warszawa 2004, s. 37).

13 Kiedy w kazaniu z 25 kwietnia 1982 roku modlił się „o wolność w Ojczyźnie”, mówił o „udręce narodu”, do antyfony powtórzonej 10-krotnie wstawił słowo lud: „Wysłuchaj, Panie, prośby ludu swego”. 
do sakralizacji polskiego narodu w imię jego cierpien ${ }^{14}$. Narodowi był skłonny - za romantykami - przypisywać cechy mesjańskie, najbardziej dobitnie w kazaniu z 26 września 1982 roku: „Tak jak Chrystus na krzyżu - Ojczyzna ocieka krwią”, wcześniej w kazaniu z 30 maja 1982 roku: „Matko nasza najlepsza, musisz cierpieć, gdy widzisz dzieci Twoje, które przeżywają swoją Kalwarię”. Wiele spraw jest „krzyżem narodu"15.

Arcybiskup Józef Życiński nie aprobował kultu narodu i przestrzegał przed jego uświęcaniem, zerwał $\mathrm{z}$ ideą mesjańskości narodu polskiego - ale niezmiennie trwał przy idei Ludu Bożego. Zastąpił patetyczny język patriotyczny nowym językiem katechetycznym, odpowiednim do epoki europeizacji i globalizacji. Ten język aktywnie współtworzył.

8. Zatrzymam się na koniec jeszcze przy kluczowym dla tego wywodu pojęciu ludu i przy sposobach jego pojmowania. Pojęcie to, używane w języku polskim często w cudzysłowie, jako cytat z przeszłości, jest różnie konceptualizowane. Genetycznie biorąc, jest to pojęcie pochodzące

${ }_{14}$ W Litanii Solidarności, odmówionej podczas Mszy św. 30 maja 1982 roku czterokrotnie przydano Matce Boskiej tytuł: Królowej Polski: cierpiacej, walczacej, niepodległej, zawsze wiernej.

${ }_{15}$ Godne podkreślenia jest to, że ks. Jerzy Popiełuszko, krytykując władze komunistyczne, nigdy nie wykluczył jej przedstawicieli z grona Polaków, przeciwnie, stale nazywał ich „rodakami”, nawet „braćmi”: „Z rąk rodaków są zabici nasi bracia”; „prosimy Boga [...] aby oświecił zaćmione umysły naszych braci”; „Tryumf nienawiści” przeszkadza „porozumieniu między braćmi”; „Bądźmy [...] silni miłością, modląc się za braci błądzących”; popełniane są „kainowe zbrodnie”. 
z tradycji szlacheckiej; przedstawiciele środowisk plebejskich, mówiąc o sobie, używają słowa naród (naród walczy, cierpi, pracuje itp.), nie lud. W polszczyźnie literackiej funkcjonują cztery profile semantyczne pojęcia ludu, które pojawiały się w różnym czasie i w różnych kontekstach historycznych. Najpierw lud był odróżniany od szlachty, ziemiaństwa, mieszczaństwa w sensie socjologicznym; od bogaczy w sensie ekonomicznym, jako biedny; od inteligencji w sensie kulturowym, jako prosty, niewykształcony, wreszcie w najnowszych czasach politycznie lud jest przeciwstawiany elicie władzy, jako ogół społeczeństwa, ludzie nieuprzywilejowani, żyjący z własnej pracy ${ }^{16}$. To ostanie jest najszersze, najbardziej zbliża się już do religijnej koncepcji Ludu Bożego, i jest bliskie obu duchownym, o których mowa.

9. Arcybiskup Józef Życiński jako kapłan czuł się pasterzem dusz, przewodnikiem Ludu Bożego. Lubił pokazywać się z pastorałem, który miał kształt prostego kija pasterskiego. Jedno z ostatnich zdjęć z roku 2010, roku jego przedwczesnej śmierci (zdjęcie nr 1), przedstawia go idącego w tłumie pielgrzymów na Jasną Górę. Idzie w otoczeniu „moherowych beretów” (!), zbratany z ludem, Ludem Bożym. To zdjęcie ma walor diagnostyczny. Arcybiskup

${ }_{16}$ Rdzenny morfem lud-w wyrazach ludzie, ludny, ludność, zaludnić, wyludnić itp. - odnosi się do znaczenia 'człowiek, homo'. Lud to po prostu ludzie. Zwężenie znaczenia słowa lud do jednego tylko stanu społecznego, chłopów, potem też stanu „plebejskiego”, zostało narzucone z zewnątrz, było rezultatem dominacji (przemocy symbolicznej) warstw uprzywilejowanych. 
Życiński doceniał rolę obrzędowości i tradycyjnych praktyk zbiorowych dla budowania więzi społecznych i podtrzymywania ducha wspólnoty. Choć sam nie ulegał tradycji, to z niej korzystał, wpływał też na jej zmiany. Jeśli zmiany te polegają - jak twierdzi Janusz Mariański - na „przekształcaniu się religijności ludowej w religijność instytucjonalną" ${ }^{17}$ i na swoistym „odczarowaniu” religijności ludowej ${ }^{18}$, to niewątpliwie abp Józef Życiński miał i chciał mieć w tym „odczarowaniu” ludowej religijności znaczący udział. W jego ustach słowo lud - w zbitce słownej Lud Boży - odzyskiwało swój sens źródłowy, etymologiczny lud to my wszyscy, podtrzymujący ludzkie więzi i wartości, bliscy sobie, pomagający sobie, solidarni.

Tak więc, podsumowując, jeśli wziąć pod uwagę to pierwotne znaczenie ludowości jako ludzkiej wspólnotowości, to niezależnie od jednostronnego postrzegania kultury wiejskiej i braku zainteresowania dla folkloru, można uznać abp. Józefa Życińskiego za duszpasterza ludowego, czyli: przyjaznego ludziom, pracującego z ludźmi i dla ludzi, dobrze pełniącego rolę przewodnika Ludu Bożego.

17 J. Mariański, Ciagłość i zmiana religijnej kultury obyczajowej, w: Kultura w kręgu wartości, red. L. Dyczewski, Lublin 2001, s. 165-176.

18 Tamże, s. 173 i nast.

Media - Kultura - Dialog. W piąta rocznicę śmierci arcybiskupa Józefa Życińskiego, red. ks. R. Nęcek, ks. W. Misztal, Kraków 2017, s. 145-158.

DOI: http://dx.doi.org/10.15633/9788374385848.14 